\title{
Diseminasi Standar Makanan, Pengolahan Jus Varian Buah dan Sayur Serta Edukasi kepada Lansia Hipertensi di Panti Sosial Tresna Werdha Budi Sejahtera Banjarbaru
}

\author{
Rijanti Abdurrachim ${ }^{1}$, Niken Widyastuti Hariati ${ }^{2}$, Endang Sri Purwanti Ningsih ${ }^{3}$ \\ ${ }^{1,2}$ Jurusan Gizi, Poltekkes Kemenkes Banjarmasin \\ ${ }^{3}$ Jurusan Keperawatan, Poltekkes Kemenkes Banjarmasin \\ Email: niken.widyastuti hariati@gmail.com
}

Submitted : 14/12/2021

Accepted: 08/01/2022

Published: 28/01/2022

\begin{abstract}
Elderly is an age group that is very vulnerable to suffer from hypertension. In addition to medication, blood pressure can be controlled by managing diet and giving fruits and vegetables.The Community Service Team carried out dissemination of food standards, processing of fruit and vegetable variant juices and education for the elderly with hypertension at the Tresna Werdha Budi Sejahtera Social Home Banjarbaru. The purpose of the activity is to provide input to nursing home managers regarding food standards, training and demonstrations of making fruit and vegetable juice variants as well as providing knowledge about eating arrangements for controlling blood pressure in the elderly. Method: Phase I: Dissemination to the management and health workers regarding food standards for the elderly with hypertension. Phase II: Conducting demonstrations of making fruit and vegetable variant juices and training nutritionists and health workers. Phase III: educating the elderly about eating arrangements and measuring blood pressure. The results of the activity: I. The results of the dissemination of suggestions for improving food standards for the elderly in order to control the blood pressure of the elderly at the Tresna Werdha Home., II The results of the juice making demonstration and training: the health workers were very enthusiastic, starting from the explanation from the preparation process to the making process. The results of education and blood pressure examinations found high grade 1 and 2 hypertension conditions. It is not possible to do pre and post-tests to explore the level of knowledge in the elderly. Asking questions directly from what is explained, all the elderly can answer. The preparation of food standards for the elderly with the addition of a composition of vegetables and fruit, the proposal to enter a joint juice drinking program with the elderly, providing continuous mentoring and motivation by nutritionists, are opportunities for the implementation of the MOU/cooperation agreement with the Social Institution.
\end{abstract}

Keywords: blood pressure, elderly, vegetable and fruit juice

\begin{abstract}
Abstrak
Lansia merupakan kelompok usia yang sangat rentan menderitahi pertensi. Selain dengan obat, tekanan darah bias dikontrol dengan pengelolaan pola makan dan pemberian buah serta sayur.Tim Pengabdian masyarakat melaksanakan diseminasi standar makanan, pengolahan Jus varian buah dan sayur serta edukasi lansia hipertensi di Panti social Tresna Werdha Budi Sejahtera Banjarbaru. Tujuan kegiatan memberikan masukan kepada pengelola panti mengenai standar makanan, pelatihan dan demonstrasi pembuatan jus varian buah sayur serta memberikan pengetahuan tentang pengaturan makan untuk pengendalian tekanan darah pada lansia. Metode: Tahap I: Diseminasi kepada pihak pengelola dan petugas kesehatan mengenai standar makanan bagi lansia hipertensi. Tahap II: Melakukan demo pembuatan jus varian buah dan sayurdan pelatihan tenaga gizi dan tenaga kesehatan. Tahap III: edukasi kepada lansia tentang pengaturan makan dan pengukuran tekanan darah. Hasil kegiatan: Hasil diseminasi usulan perbaikan standar makanan bagilansia guna pengendalian tekanan darah lansia di Panti Tresna Werdha, Hasil demo pembuatan jus dan pelatihan:petugas kesehatan sangat antuasias mulai dari penjelasan dari proses persiapan sampai dengan proses pembuatan. Hasil edukasi dan pemeriksaan tekanan darah ditemukan kondisi hipertensi tingkat 1 dan 2 yang tinggi. Tidak bisa dilakukan pre dan post
\end{abstract}


test untuk menggali tingkat pengetahuan pada lansia. Pemberian pertanyaan langsung dari apa yang dijelaskan, semua lansia bisa menjawab.Tersusunnya standar makanan lansia dengan penambahan komposisi sayur dan buah, usulan masuk dalam program minum jus bersama dengan lansia, adanya pendampingan dan motivasi secara kontinyu oleh ahli gizi, menjadi peluang untuk pelaksanaan MOU/ perjanjian kerja sama dengan Panti Sosial.

Kata Kunci: jus sayur dan buah, lansia, tekanan darah

\section{PENDAHULUAN}

Panti Sosial Tresna Werdha Budi Sejahtera merupakan salah satu unit pelaksanaan dari Dinas Sosial Provinsi Kalimantan Selatan yang dalam kegiatannya memberikan pelayanan sosial kepada lansia. Berdasarkan data yang diambil dari Kepala Panti Sosial Tresna Werdha Budi yang berada di dua tempat yaitu di Landasan Ulin dan Martapura jumlah lansia yang ada di panti 170 orang . Data dari klinik di Panti sosial diketahui penyakit hipertensi selalu menempati urutan 3 besar penyakit terbanyak setiap bulannya dalam rentang tahun 2016 sampai April 2018. Jumlah lansia di Landasan Ulin dengan hipertensi berjumlah kurang lebih 30 orang dan sisanya berada di Martapura.

Mitra dalam hal ini adalah lansia di panti khususnya dengan penyakit hipertensi bisa dikontrol dengan selalu mengkonsumsi obat anti hipertensi dan selalu mengontrol keadaan tekanan darah. Penderita tekanan darah tinggi juga bisa mengontrol tekanan darah dengan cara menghindari makanan yang tinggi kolesterol dan banyak kandungan lemak. Pengobatan hipertensi dikombinasikan dengan berbagai komplek obat diuretik seperti hydrochlorothiazide.

Beberapa buah dan sayuran yang dapat menurunkan tekanan darah adalah semangka ,mentimun, tomat, sawi hijau, papaya dan pisang Ambon. Kandungan air, vitamin $\mathrm{C}$ dan vitamin $\mathrm{A}$ (karotenoid) dan vitamin $\mathrm{K}$ pada semangka juga berperan penting. Air merupakan pelarut dan membawa sampah hasil metabolisme tubuh sehingga natrium dapat dikeluarkan melalui urin. Vitamin C dapat memperkuat otot jantung dan berperan penting dalam proses metabolisme kolesterol, dengan meningkatkan laju kolesterol yang dibuang dalam bentuk asam empedu(Utami and Kusumastuti, 2014).

Buah dan sayuran yang baik dalam pengendalian tekanan darah yaitu seperti halnya pada hasil penelitian yang dilaksanakan di Panti Sosial tahun 2019 bahwa tomat, sawi dan semangka pisang ambon sangat baik sangat baik dan efektif dalam pengendalian tekanan darah untuk penderita hipertensi. Suatu makanan dikatakan makanan yang sehat untuk pembuluh darah dan jantung, dimana makanan tersebut mengandung kalium yang merupakan elektrolit intraseluler yang utama, dalam kenyataan, 98\% kalium tubuh berada di dalam sel, $2 \%$ sisanya berada di luar sel, yang penting adalah $2 \%$ ini untuk fungsi neuromuskuler (Hariati and Abdurrachim, 2020).

Dari hasil observasi di Panti Sosial Tresna Werdha Budi Sejahtera mengenai pemberian makanan untuk lansia diketahui bahwa standar pemberian makanan sama untuk semua lansia yang hipertensi ataupun tidak hipertensi, dimana dalam pemasakan sudah diterapkan pengurangan penggunaan garam. Namun belum ada hitungan kandungan natrium dan kalium dalam standar makanan di panti.

Pemberianstandar makanan diberikan kepada semua penghuni panti tersebut. Dalam siklus menu, terdapat beberapa menu yang tidak sesuai dengan syarat diet. Misalnya, masih ada makanan yang ditambahkan bumbu seperti kecap yang merupakan sumber natrium dan untuk lauk masih banyak yang digoreng, sedangkan 
untuk lansia makanan yang digoreng harus dibatasi.

\section{TARGET DAN LUARAN}

\section{Target}

1. Pihak manajemen memahami usulan standar makanan yang diharapkan sudah sesuai dengan standar makanan untuk lansia hipertensi dan bisa diterima usulan pemberian jus untuk dapat diterapkan sebagai standar makanan lansia di panti untuk pengendalian tekanan darah dengan memperhatian rasio natrium: kalium adalah 1: >=1.

Target: susunan standar makanan lansia tinggi kalium yang telah didiseminasikan untuk dapat diterima dan selanjutnya dapat dilaksanakan di panti sosial .

2. Demo pembuatan jus sayur tomat sawi+buah semangka, pisang ambon dapat terlaksana serta pelatihan tenaga gizi dalam menyiapkan jus varian sayur dan buah dalam standar makanan di panti sosial.

Targetnya:tenaga gizi dapat mencoba menyiapkan jus sayuran dan buah sesuai dengan standar cita rasa nya.

3. Edukasi tentang pengaturan makan dalam pengendalian tekanan darah dapat terlaksana guna menambah pemahaman tentang penyakit hipertensi, gejala, pengendalian tekanan darah dengan mengonsumsi banyak buah dan sayur dan pola hidup yang baik.

Target capaian ada peningkatan pemahaman dari lansia dengan tidak mengonsumsi bahan makanan dan makanan kemasan yang tinggi natrium dari luar panti sosial, sehingga harapannya tekanan darah dapat terkendali dan pemeriksaan tekanan darah oleh tim pengabmas dapat menunjukkan gambaran tekanan darah lansia.

\section{Luaran}

Hasil pengabdian kepada masyarakat ini diharapkan dapat dipublikasikan melalui jurnal pengabdian masyarakat dan luaran lainnya berupa dokumentasi dan video kegiatan.

\section{METODE PELAKSANAAN Sasaran Kegiatan}

1. Pengelola panti sosialsebagai pengambil kebijakan dan petugas gizi sebanyak 17 orang dapat memahami pentingnya pemberian buah dan sayuran yang cukup sebagai sumber kalium guna pengendalian hipertensi. Pemahaman standar makanan di panti sosial khususnya dalam kandungan natrium dan kalium .

2. Petugas gizi dan petugas kesehatan sebagai orang yang melaksanakan pelayanan gizi dan tenaga kesehatan berjumlah 12 orang. Mengikuti kegiatan demo dan pelatihan pembuatan jus varian buah dan sayur serta merasakan jenis jus varian buah dan sayur yang paling disukai.

3. Lansia hipertensi yang telah diedukasi tentang pengendalian tekanan darah sebanyak 32 orang.

\section{Metode Kegiatan}

Kegiatan pengabdian dilakukan melalui beberapa kegiatan yaitu :

a. Tahap I:

Memberikan masukan kepada pihak pengelola dan petugas kesehatan mengenai standar makanan bagi lansia hipertensi

b. Tahap II:

1. Melakukan demo pembuatan jus varian buah dan sayur kepada tenaga gizi dan tenaga kesehatan .

2. Melatih tenaga gizi cara membuat jus varian sayur dan buah

c. Tahap III:

Membuat jus varian buah dan sayur serta edukasi kepada lansia tentang pengaturan makan untuk pengendalianhipertensi lansia dan pengukuran tekanan darah.

Waktu dan Tempat Kegiatan 
Pengabdian masyarakat ini akan dilaksanakan pada bulan April-Juni 2021 selama kurun waktu 3-bulan di Panti Sosial Tresna Werdha

\section{Alat dan Bahan}

1. Alat yang digunakan untuk kegiatan edukasi adalah :

Tahap I: Standar makanan lansia hipertensi di Panti Werdha

Tahap II: Blender, pisau, talenan, sendok makan, baskom, timbangan digital, gelas ukur dan cup plastic

Tahap III: Leaflet hipertensi, LCD,

2. Bahan yang digunakan :

Tomat, Sawi,Semangka, Pisang Ambon.

\section{Pihak yang Terlibat}

Pihak-pihak yang terlibat dalam kegiatan ini adalah 3 dosen dan 3 mahasiswa dibantu oleh supir dan tenaga gizi di panti sosial.

\section{Penilaian}

Untuk menilai tingkat keberhasilan kegiatan ini dilakukan penilaian:

a. Tahap I:Diseminasi kepada pengelola Panti Werdha.

Penilaian dengan melihat respons dari pihak pengelola mengenaipenjelasan; denganadanya pertanyaanpertanyaanyang diajukan.

b. Tahap II: Demonstrasi pembuatan jus dan pelatihan pembuatan jus varian sayur dan buah.

Melihat respons dari tenaga gizi dalam pembuatan jus varian sayur dan buah melaui demo dan pelatihan,dengan melihat hasil berupa ketrampilan membuat jus varian sayur dan buah sesuai standar. Serta memperoleh masukkan pilihan rasa jus varian buah dan sayur yang dipilih hasil penilaian cita rasa oleh peserta pelatihan.

c. Tahap III: pemberian edukasi kepada lansia tentang pengaturan makan untuk pengendalian hipertensi bagi lansia dan pengukuran tekanan darah.
Telah memberikan test langsung berupa pertanyaan singkat setelah diberikan edukasi, semula merencanakan dengan menilai pre dan post-test namun tidak bisa terlaksana karena faktor keterbatasan faktor usia. Setelah edukasi yang disampaikan kepada lansia langsung diberikan beberapa pertanyaan kepada lansia mengenai materi pengaturan makan dalam pengendalian hipertensi bagi lansia,serta dilakukan pengukuran tekanan darah. Harapan pengetahuan lansia bertambah tentang penyakit hipertensi, manfaat jus sayur dan buah dengan kandungan kalium di dalamnya, serta lansia akan menghabiskan jus sayur dan buah untuk menambah kalium dari sayur dan buah guna membantu pengendalian tekanan darah sistolik dan diastolik, selain kepatuhan dalalm minum obat untuk hipertensi.

\section{HASIL DAN PEMBAHASAN Diseminasi Standar Makanan}

Kegiatan pertama yaitu diseminasi standar makanan di panti sosial telah dilaksanakan pada tanggal 5 April 2021 dihadiri oleh pengelola panti serta tenaga gizi dan kesehatan berjumlah 17 orang. Hasil yang dicapai adalah telah disampaikannya standar makanan yang telah dilaksanakan selama ini sudah sesuai dengan Angka Kecukupan Gizi (AKG)Kemenkes RI (2013) namun proporsi antara kandungan natrium dan kalium yang belum sesuai. Kandungan kalium dalam standar makanan yang ada sekarang hanya 1157,5 mgsedangkan standar kecukupan kalium adalah 4700 mg (Kemenkes RI, 2019).Kandungan natrium dalam standar makanan 1276,3 mg sudah sesuai dengan kecukupan natrium yaitu $1233 \mathrm{mg}$. Hal tersebut telah disampaikan bahwa perbandingan kandungan natrium dan kalium sebaiknya adalah 1:>1 untuk 
pengendalian tekanan darah. Hal ini sesuai dengan Lestari (2010)bahwa kalium dan magnesium berpengaruh dalam membantu menurunkan tekanan darah.

Respon dari hasil diseminasi adalah adanya respons pertanyaan terkait dengan tekanan darah dan makanan:

a. Varian buah dan sayur yang baik untuk lansia terkait dengan rasa.

b. Cara membuat nya

c. Bagaimana hasil jus yang diterima oleh lansia.

Hasil diseminasiterlihat respons dari audiens dengan adanya beberapa pertanyaan, dan informasi ini akan dibicarakan oleh pihak pengelola terkait untuk masukkan perbaikan standar makanan bagi lansia guna pengendalian tekanan darah lansia di Panti Tresna Werdha.

\section{Kegiatan 1. Diseminasi Standar Makanan}
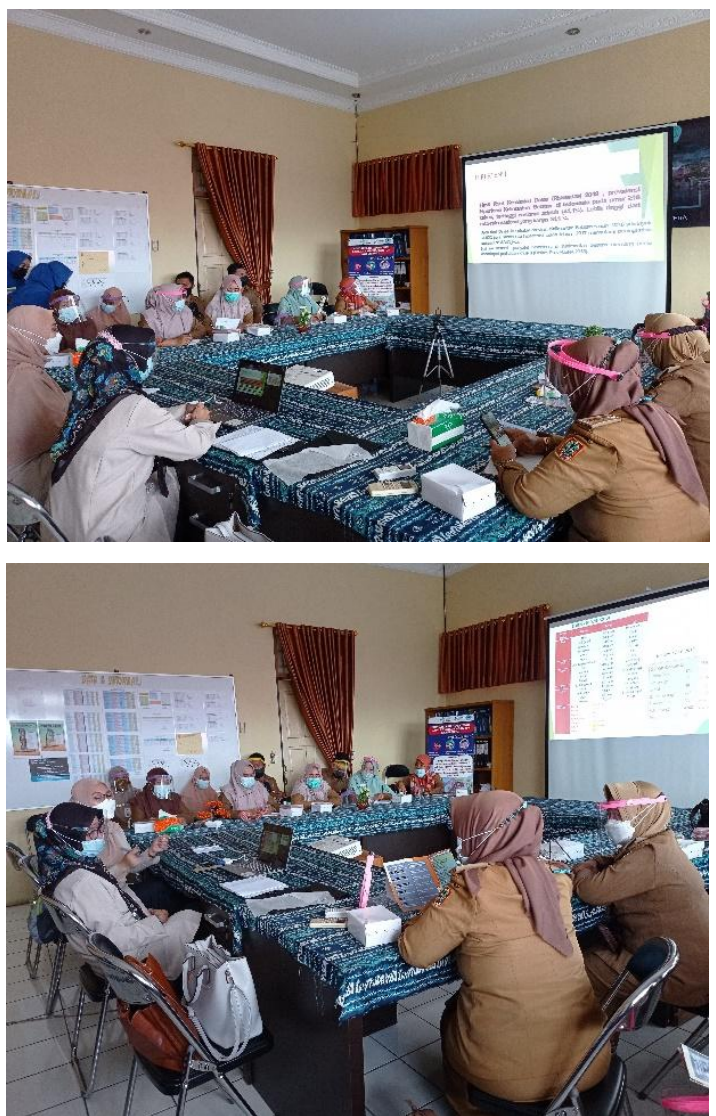

Kegiatan Demo Pembuatan Formula Jus Sayur dan Buah
Melakukan demo pembuatan jus varian buah dan sayur kepada tenaga gizi dan tenaga kesehatan dilaksanakan pada hari Jumat, tanggal 9 April 2021.Untuk melatih tenaga gizi cara membuat jus varian sayur dan buah yang terdiri dari 2 varian, yaitu: Sawi, tomat + Semangka dan Sawi, tomat + Pisang Ambon.

Saat melaksanakan Demo pembuatan jus varian buah dan sayur dihadiri sejumlah 12 orang petugas gizi dan tenaga kesehatan. Kegiatan ini diawali dengan melaksanakan presensi kehadiran serta pemberian lembaran yang berisi cara pembuatan jus varian sayur dan buah komposisi nilai kalori dan zat gizi (natrium, kalium dan magnesium).

Tim pengabmas menyiapkan demo pembuatan jus buah, yaitu: persiapan mencuci bahan sayur dan buah, persiapan alat-alat yang akan dipakai. Setelah persiapan selesai, dilakukan pembukaan berupa sambutan oleh ketua tim pengabmas dan dilanjutkan dengan penjelasan mulai dari persiapan:

1). Awal mencuci bahan dengan air mengalir, kemudian dilanjutkan dengan air matang hangat dengan mencampur dengan garam guna menghilangkan telur-telur cacing dan pestisida yang ada pada sayuran yang digunakan yaitu sawi hijau, tomat.

2).Menjelaskan cara membuat jus varian buah dan sayur bersama dengan mendemonstrasikannya oleh tim pengabmas,serta memberikan kesempatan peserta untuk mencoba jus sayur dan buah.

3). Mencobakan jus yang telah jadi kepada peserta yang terdiri dari 2 macam jus varian dan memberikan penilaian dari segi daya terima.

4). Mendapatkan hasil dari penilaian daya terima jus yang lebih disukai.

Jus yang lebih disukai melalui penilaian rasa yang lebih dapat diterima yaitu rasa segar perpaduan yang muncul dari rasa buah pisang ambon, manis dari 
madu dan aroma serta rasa jeruk nipis menghilangkan rasa langu dari sawi hijau. Penilaian warna jus cukup menarik hijau dari warna sawi dan pisang ambon.

Terlihat antusias dari mereka mulai dari penjelasan oleh tim pengabmas dalam langkah-langkah proses persiapan mulai dari mencuci sayuran dengan air mengalir dan perendaman dengan garam dan air hangat guna menghilangkan pestisida dan mematikan mikroba yang ada pada sayur dan buah serta pembuatan jus sampai dengan pendistribusian. Menurut (Tri Widianingsih, Yuliana and Suardana, 2019)bahwa perlu pencucian sayuran dengan air bersih yang mengalir untuk menghilangkan cacing dari tanah dan pestisida yang menempel pada sayuran.

Hasil dari uji cita rasa dari segi rasa dan penampilan dimana sebanyak 11 orang (90 \%) mengatakan rasa makanan terpilih enak dari varian tomat, sawi ditambah pisang ambon. Kombinasi manis dan rasa khas dari pisang ambon memunculkan rasa yang khas. Rasa jus dengan aroma dari jeruk nipis dan pisang ambon serta rasa manis dari madu membuat pilihan terbanyak pada varian tersebut, menghilangkan rasa langu dari sawi hijau yang khas. Satu orang (10 \%)kurang suka aroma dari pisang ambon.

Sedangkan dari segi tampilan, memberikan pendapat yang sama antara varian 1 dan 2. Kedua varian penampilannya dominan hijau dari sawi. Varian sayur buah 1 , memberikan warna hijau agak kemerahan dari warna sawi hijau serta warna merah dari tomat dan semangka. Varian sayur buah 2, memberikan warna hijau dari sawi dan warna tomat tidak tampak merah karena pisang ambon memberikan warna agak kekuningan kearah gelap menjadi kecoklatan. Bila dari penampilan, 7 orang dari 12 orang $(58 \%)$ mengatakan varian jus 1 lebih baik dan 5 orang (42\%) mengatakan warna hijau dari jus varian 2 yang menarik. Hampir sama penilaian dari warna .

\section{Kegiatan 2. Demo dan Pelatihan Pembuatan Jus}
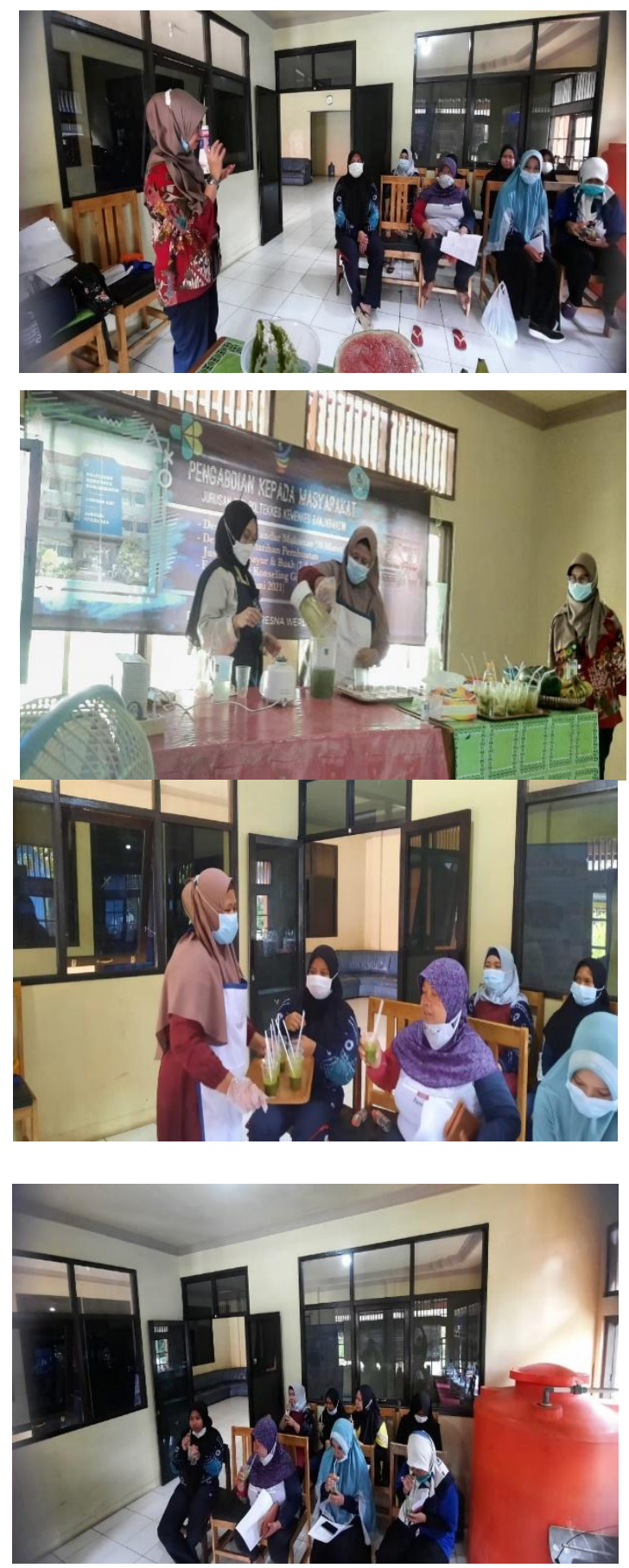

\section{Kegiatan 3.Edukasi Kepada Lansia Hipertensi}

Kegiatan pemberian edukasi kepada lansiamengenai makanan yang dilaksanakan pada hari Selasa tanggal 15 Juni 2021 untuk pengendalian tekanan darah oleh tim pengabmas. Semula data 
lansia yang mandiri berjumlah 35 orang, namun dalam pelaksanaan edukasi hanya bisa dilaksanakan edukasi pada 32 lansia terpilih dengan kategori hipertensi dan lansia yang mandiri. Sarana yang digunakan adalah leaflet, lembar pertanyaan dan alat ukur tekanan darah digital.

Kegiatan ini dilaksanakan oleh tim pengabmas dari Poltekkes Kemenkes Banjarmasin yang dibantu oleh 3 orang mahasiswa. Langkah-langkah kegiatan:

\section{a). Persiapan:}

1). Mendata lansia yang hipertensi di masing-masing wisma dimana tempat tinggal lansia. Data diperoleh dari klinik di PTSW . Kriteria lansia yang dipilih adalah lansia yang mandiri dan kooperatif. Diperoleh data dari Panti Sosial sejumlah 35 orang lansia hipertensi mandiri.

2). Melaksanakan edukasi: Lansia hipertensi berjumlah 32 orang dengan jenis kelamin perempuan 18 orang (56\%) dan 14 orang laki-laki (44\%). Lansia dilakukan pemeriksaan tekanan darah dan diberikan edukasi tentang penyakit hipertensi, pengendalian tekanan darah dengan istirahat cukup, makan makanan yang cukup natrium dan kalium, bahan makanan yang harus dibatasi seperti kecap, dll dan dihindari seperti makanan yang asin, makanan kaleng, dll. Alat bantu dengan leaflet.Rencana semula Lansia akan dilaksanakan pretest dan post test sebelum dan setelah edukasi,namun dalam pelaksanaanaanya tidak bisaterlaksana karena lansia mempunyai keterbatasan dalam menjawab dan menulis. Akhirnya pertama dilakukan edukasi dan langsung diberikan beberapa pertanyaan ringan tentang makanan yang bisa meningkatkan tekanan darah, makanan yang tinggi natrium dan bahan makanan yang tinggi kalium dari sayuran dan buah. Pertanyaan tersebut untuk menilai evaluasi bagaimana penerimaan edukasi yang diberikan.

Kegiatan 3. Edukasi lansia

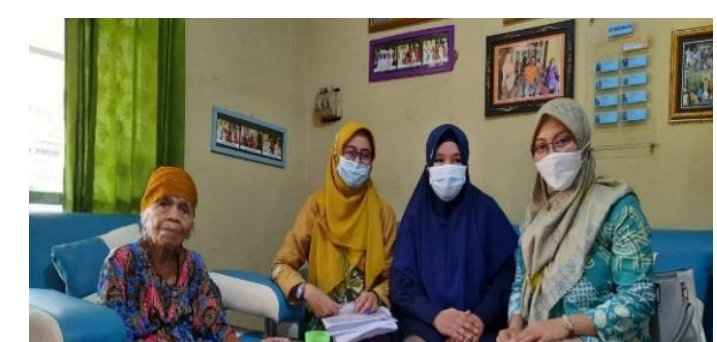

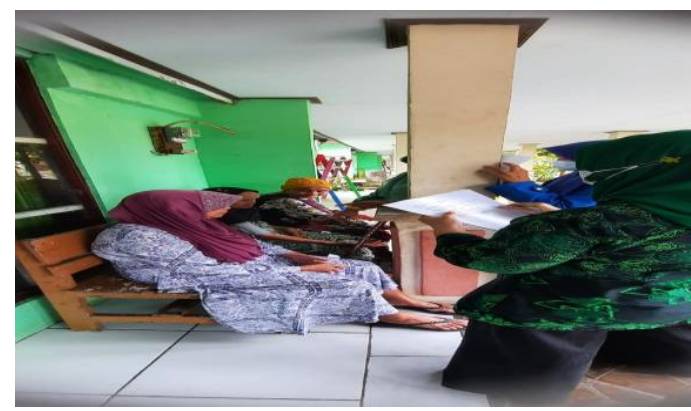

b). Hasil pelaksanaan :

Hasil pengukuran tekanan darah sesaat saat diberikan edukasi diperoleh: 8 orang $(25 \%)$ pada kondisi normal, pra hipertensi 6 orang (19\%), kondisi hipertensi tingkat 1 sebanyak 12 orang $(37 \%)$ dan 6 orang (19\%) masuk kategori hipertensi tingkat 2 . Dapat dilihat pada Gambar 1. Distribusi Frekuensi Kategori Hipertensi.

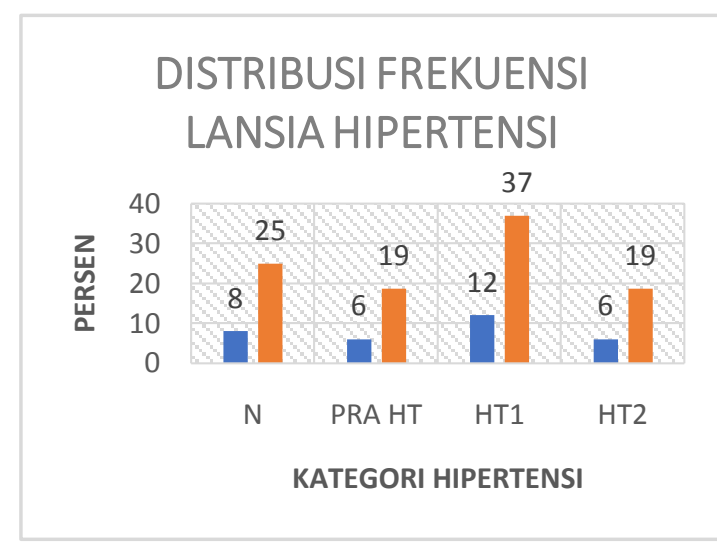

$$
\text { Menurut WHO, hipertensi }
$$
didefinisikan sebagai keadaan tekanan darah sistolik $\geq 140 \mathrm{mmHg}$ dan atau tekanan darah diastolik $\geq 90 \mathrm{mmHg}$. Menurut Joint National Committee on Prevention, Detection, Evaluation, and Treatment on High Blood Pressure (JNC VII) hipertensi diklasifikasikan seperti berikut:
Tabel
1. Klafikasi
Hipertensi 


\begin{tabular}{lcc}
\hline Klasifikasi Darah & $\begin{array}{c}\text { Tekanan } \\
\text { Darah } \\
\text { Sistolik } \\
(\mathrm{mmHg})\end{array}$ & $\begin{array}{c}\text { Tekanan } \\
\text { Darah } \\
\text { Diastolik } \\
(\mathrm{mmHg})\end{array}$ \\
\hline Normal & $<120$ & $<80$ \\
Prehipertensi & $120-139$ & $80-89$ \\
Hipertensi Stage 1 & $140-159$ & $90-99$ \\
Hipertensu Stage 2 & $\geq 160$ & $\geq 100$ \\
\hline
\end{tabular}

Hasil edukasi tentang pemberian makanan yang baik untuk pengendalian tekanan darah dapat dilihat pada grafik 2 . Hasil penilaian terhadap bagaimana penerimaan dan pemahaman responden terhadap edukasi yang diberikan diperoleh bahwa $72 \%$ mempunyai penerimaan edukasi baik, yaitu mereka dapat menerima penjelasan yang diberikan dan dapat menjawab langsung apa yang ditanyakan kembali oleh tim pengabmas.

Sebanyak $16 \%$ mempunyai pengetahuan kurang dan $12 \%$ mempunyai pengetahuan cukup. Pertanyaaan yang bisa dijawab lansia adalah penyebab hipertensi, gejala yang dirasakan oleh penderita hipertensi, dan makanan yang dilarang. Namun pengetahuan yang tidak diketahui oleh lansia yaitu sumber makanan yang mengandung tinggi kalium, gejala tekanan darah tinggi dan bahan makanan yang dihindari untuk mencegah tekanan darah tinggi.

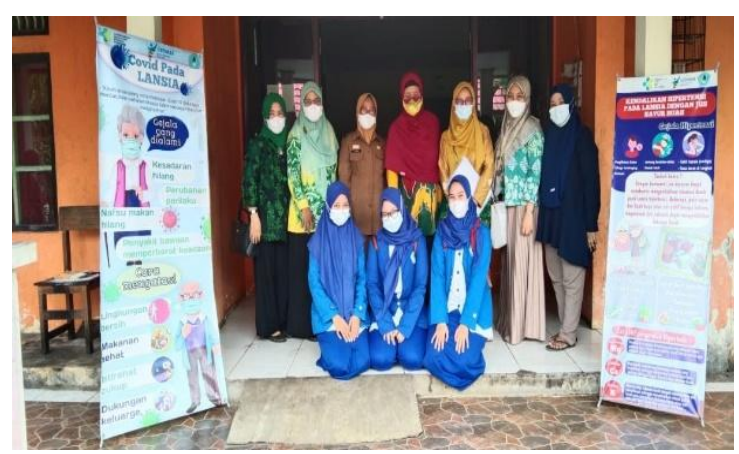

\section{DISTRIBUSI PENGETAHUAN} LANSIA

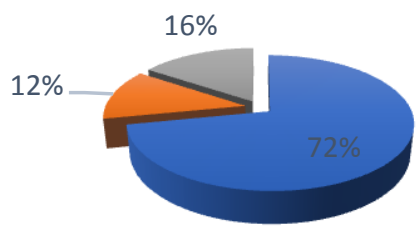

-BAIK CUKUP KURANG

\section{Gambar2.Distribusi lansia berdasarkan kategori pengetahuan}

Setelah dilakukan test, lansia diberikan jus varian sayur 2 yaitu: Sawi, tomat dan pisang Ambon masing-masing 1 cup es krim.

\section{Respons lansia dalam menerima jus:}

Mereka menerima untuk mengonsumsi dan menghabiskannya, hal ini menunjukkan bahwa edukasi yang disampaikan, manfaat dari jus sayur dan buah yang tinggi kalium baik dikonsumsi untuk mengendalikan tekanan darah dapat diterima/ dipahami. Hal ini sesuai dengan penelitian Hariati and Abdurrachim (2020)yaitu jus buah varian sawi tomat dan pisang ambon kaya akan kandungan Kalium dapat menurunkan tekanan darah sistolik lansia.

Secara keseluruhan hasil kegiatan ini, terlihat interaksi yang baik dengan lansia, dengan memberikan respons dari pertanyaan yang diajukan. Tampak lansia sangat senang mendapat perhatian dari tim pengabmas. Perlu pendampingan secara rutin dan mendalam guna memberikan perhatian dan edukasi secara berulang, dengan demikian lansia merasa diperhatikan dan mudah diawasi makanan yang diberikan dari luar. Hal ini sesuai dengan kegiatan pengabmas yang dilakukan oleh Suprayitno and Huzaimah (2020) keberhasilan pendampingan lansia untuk menumbuhkan motivasi dalam pencegahankomplikasi penyakit hipertensi 
adalah dengan antusias dan semangat dalam mengikuti kegiatan pendampingan.

Selain itu lansia juga aktif dalam melakukan tanya jawab dengan pendampingan dan berdiskusi tentang pencegahan komplikasi hipertensi. Pelaksanaan kegiatan pengabdian ini sesuai harapan yaitu kelancaran proses edukasi dan diskusi tanpa adanya hambatan yang cukup berarti.

Pemberian edukasi dan pemberian formula jus sawi tomat dan pisang ambon dapat membantu menambah asupan kalium dalam makanan sehari-hari. Bila diberikan tambahan dalam bentuk buah, selain standar buah dan sayur dari panti sosial harapannya sangat sulit dipenuhi, karena menambah jumlah volume buah yang harus ditambahkan dalam hidangan sehari yang mungkin sulit untuk menghabiskan.

Penambahan kalium dari varian jus sayur dan buah yang terdiri dari sayur sawi+tomat dan buah pisang ambon dapat menyumbangkan kalium sekitar 180 $\mathrm{mg} /$ hari. Pemberian jus ini salah satu mendukung stabilnya tekanan darah lansia selain faktor usia, riwayat keluarga, faktor stress, kebiasaan beraktifitas fisik. Hasil penelitian Imammudin (2016)menyebutkan tidak adanya hubungan asupan kalium dengan tekanan darah sistolik disebabkan ada faktor lain seperti usia, kebiasaan berolahraga, stress dan riwayat keluarga.

Mekanisme kalium menurunkan tekanan darah antara lain menurunkan produksi vasokonstriktor thromboxane dan meningkatkan produksi vasodilasator kalidin sehingga terjadi vasodilatasi pada pembuluh darah.Vasodilatasi ini menyebabkan penurunan resistensi perifer dan meningkatkan curah jantung. Kalium sebagai salah satu mineral yang menjaga keseimbangan cairan dan elektrolit mempunyai efek natriuretika dan diuretika yang meningkatkan pengeluaran natrium dan cairan dari dalam tubuh. Kalium juga menghambat pelepasan renin sehingga mengubah aktifitas renin angiotensin dan mengatur saraf perifer dan sentral yang mempengaruhi tekanan darah (Imammudin, 2016). Sumber utama kalium adalah makanan mentah/segar, terutama sayuran, dan kacang-kacangan. Kacang merah, kacang tanah, pisang, alpokat, bayam, dll (Almatsier, 2009).

\section{Luaran yang dicapai.}

Luaran yang dicapai dalam pengabdian masyarakat ini adalah

- Video kegiatan pengabdian kepada masyarakat (Jangka Pendek)

- Peluang terlaksananya MOU antara Poltekkes Banjarmasin dan Panti SosialTresna Werdha dalam pelaksanaan Tri Dharma Perguruan Tinggi. Diharapkan dapat menjadi lahan untuk Pendidikan,Praktek Lapangan dan PengabdianMasyarakat Mahasiswa dan Dosen (Jangka Menengah).

- Memasukkan kegiatan dalam program minum bersama jus varian sayur dan buah dalam setiap kesempatan berkumpul semua lansia, untuk mendukung pengontrolan tekanan darah (Jangka Pendek). Hasil diskusi dengan pengelola gizi di Panti Sosial untuk diajukan sebagai salah satu metodenya.

- Submit ke dalam jurnal Pengabdian Masyarakat (Jangka Menengah).

\section{KESIMPULAN DAN SARAN}

\section{Kesimpulan}

Perlu disusun kembali suatu standar makanan yang sesuai komposisi kandungan natrium dan kalium, dengan penambahan konsumsi sayur dan buahdalam standar makanan. Pemberian Jus varian sayur sawi, tomat dan pisang ambon dalam sajian 1 gelas $150 \mathrm{cc}$ dalam sehari dalam standar makanan yang diajukan. Kelemahan dari lansia yaitu apabila diberikan makanan atau minuman sering lupa untuk diminum. Jadi saran pemberian adalah dukungan pengasuh wisma untuk selalu menganjurkan dan menunggu untuk segera diminum.

Selain itu kegiatan minum jus varian sayur dan buah dikemas dalam suatu acara 
edukasi gizi dan kesehatan secara berkala yang didalamnya dilaksanakan acara minum jus sayur dan buahbersama-sam auntuk semua lansia, sehingga lansia akan lebih merasakan pentingnya konsumsi sayur dan buah dalam hal ini dalam bentuk minuman jus varian sayur dan buah.

\section{Saran}

Perlua danya pendampingan dan motivasi kepada lansia secara kontinyu oleh ahligizi dan pendamping wisma untuk mematuhi pengaturan makanan guna pengendalian tekanan darah pada lansia.

Kepada pihak manajemen bisa dilanjutkan dengan bentuk kerjasama dengan Poltekkes Kemenkes Banjarmasin untuk kegiatan Tri Dharma Perguruan Tinggi yang meliputi: Pendidikan, Penelitian dan Pengabdian Kepada Masyarakat bagi Dosen dan Mahasiswa.

\section{UCAPANTERIMAKASIH}

Ucapan terimakasih kepada pihak manajemendari Panti Sosial Tresna Werdha yang telah memberikan kesempatan kepada tim pengabmas untuk mengabdikan hasil penelitian yang telah dilakukan. Begitu juga ucapan kepada tenaga gizi dan tenaga kesehatan lainnya yang mendukung kegiatan ini.

\section{DAFTAR PUSTAKA}

Almatsier, S. (2009) Prisip Dasar Ilmu Gizi. Jakarta: Gramedia.

Hariati, N. W. and Abdurrachim, R. (2020) 'Fruit and vegetable juice formulation for blood pressure control in hypertensive elderly', Jurnal Gizi dan Dietetik Indonesia (Indonesian Journal of Nutrition and Dietetics), $8(1), \quad$ p. $45 . \quad$ doi: 10.21927/ijnd.2020.8(1).45-53.

Imammudin, W. P. (2016) Hubungan Antara Asupan Kalium Dengan Tekanan Darah Pada Lanjut Usia Di Posyandu Lansia Ngudi Waras Di Desa Blulukan, Kecamatan Colomadu, Karanganyar, Jawa
Tengah. Universitas Muhammadiyah Surakarta. Available at: http://eprints.ums.ac.id/47194/3/03. HALAMAN DEPAN.pdf.

Kemenkes RI (2013) 'Angka Kecukupan Gizi Bangsa Indonesia', Menteri Kesehatan Republik Indonesia Peraturan Menteri Kesehatan Republik Indonesia, 1(2), pp. 99-117. Available at: https://peraturan.bpk.go.id/Home/Do wnload/130524/Permenkes Nomor 75 Tahun 2013.pdf.

Kemenkes RI (2019) 'Angka Kecukupan Gizi Mayarakat Indonesia', Menteri Kesehatan Republik Indonesia Peraturan Menteri Kesehatan Republik Indonesia, Nomor 65(879), pp. 2004-2006. Available at: https://peraturan.bpk.go.id/Home/Det ails/138621/permenkes-no-28-tahun2019.

Lestari, D. (2010) 'Hubungan Asupan Kalium, Kalsium, Magnesium, dan Natrium, Indeks Massa Tubuh, serta Aktifitas Fisik dengan Kejadian Hipertensi pada Wanita Usia 30 - 40 Tahun', Program Studi Ilmu Gizi Fakultas Kedokteran Universitas Diponegoro Semarang, (Badan Penerbit Fakultas Kedokteran Universitas Diponegooro), pp. 235248.

Suprayitno, E. and Huzaimah, N. (2020) 'Pendampingan Lansia Dalam Pencegahan Komplikasi Hipertensi', SELAPARANG Jurnal Pengabdian Masyarakat Berkemajuan, 4(1), p. 518. doi: 10.31764/jpmb.v4i1.3001.

Tri Widianingsih, N. K., Yuliana, E. D. and Suardana, A. A. K. (2019) 'Kontaminasi Soil Transmitted Helmiths Pada Helaian Daun Dan Cara Pencucian Sayuran Kubis Di Pasar Tradisional Kabupaten Tabanan', Jurnal Widya Biologi, 10(01), pp. 54-67. doi: 10.32795/widyabiologi.v10i01.237. 
Utami, R. W. and Kusumastuti, A. C. (2014) 'Pengaruh Vitamin C Terhadap Kadar High Density Lipoprotein (HDL) Lanjut Usia Setelah Pemberian Jus Lidah Buaya (Aloe Barbadensis Miller)', 3(4), pp. 737-744. Available at: https://media.neliti.com/media/public ations/95807-ID-pengaruh-vitamin-cterhadap-kadar-high-d.pdf. 